\title{
Article
}

\section{From theory to impact: bringing work-life initiatives into the mainstream.}

Smithson, Janet, Chatrakal Na Ayudhya, Uracha and Sullivan, Cath Available at http://clok.uclan.ac.uk/14042/

Smithson, Janet, Chatrakal Na Ayudhya, Uracha and Sullivan, Cath ORCID: 0000-0001-5417-8945 (2016) From theory to impact: bringing work-life initiatives into the mainstream. Community, Work and Family, 19 (2). pp. 129133. ISSN 1366-8803

It is advisable to refer to the publisher's version if you intend to cite from the work. http://dx.doi.org/10.1080/13668803.2016.1134114

For more information about UCLan's research in this area go to http://www.uclan.ac.uk/researchgroups/ and search for < name of research Group>.

For information about Research generally at UCLan please go to http://www.uclan.ac.uk/research/

All outputs in CLoK are protected by Intellectual Property Rights law, including Copyright law. Copyright, IPR and Moral Rights for the works on this site are retained by the individual authors and/or other copyright owners. Terms and conditions for use of this material are defined in the policies page.

\section{CLoK}

Central Lancashire online Knowledge www.clok.uclan.ac.uk

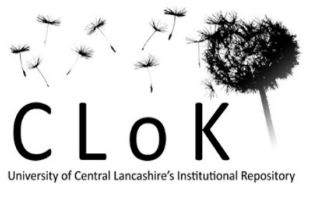




\title{
Introduction
}

From theory to impact: Bringing work-life initiatives into the mainstream ${ }^{1}$

\author{
Janet Smithson ${ }^{1}$, Uracha Chatrakul na Ayudhya ${ }^{2}$ and Cath Sullivan ${ }^{3}$ \\ ${ }^{1}$ Department of Psychology, University of Exeter, Exeter, UK \\ ${ }^{2}$ Leadership, Work, and Organisations Department, Middlesex \\ University Business School, London, UK \\ ${ }^{3}$ School of Psychology, University of Central Lancashire, Preston, UK.
}

\section{Introduction}

In this special issue we focus on the work and influence of Sue Lewis, one of the Community, Work and Family Journal's two founding editors. In launching this journal Sue, together with Carolyn Kagan, aimed to encourage debate and critical examination of, and reflection on, existing perspectives, frameworks and practices (Kagan and Lewis, 2015). They also explicitly aimed "to publish work that challenged the status quo, encouraged personal reflection and reflexivity, and put professional and lay views side by side" (Kagan and Lewis, 2015). For this special issue we invited researchers who have worked with Sue at different stages of her career - from her Ph.D. supervisor (Cary Cooper) some of her international research partners Marcie Pitt-Catsouphes, Ellen Kossek), her previous colleagues at Manchester Metropolitan University (Carolyn Kagan, Rebecca Lawthom), her national and international research partners on a series of European projects (Julia Brannen, Ann Nilsen, Laura den Dulk, Bram Peper), through to one of Sue's recent Ph.D. students and early career researcher (Uracha Chatrakul Na Ayudhya. In the articles that are to follow, the authors draw upon and highlight the considerable and invaluable influences that Sue's work has had in the field of Community, Work and Family.

The fact that the authors of these papers have had relationships with Sue that span several decades means that the papers focus on a variety of areas, but some common themes recur throughout the issue. Below we draw out some of these recurring themes and highlight Sue's influence in this area:

\section{Highlighting gaps between policy and practice}

A key role that Sue has consistently played, identified by many of her research collaborators, is the insistence on focusing not just on theory but on how research can change organisational practice. Brannen and Nilsen describe Sue's approach as "particularly renowned by her interrogation of work-family policies introduced by employers and the state and how they are enacted (or not) in practice." Den Dulk et al note that "Her work provides evidence of the gap between policy and practice and highlights the paramount importance of organizational culture and informal supervisory support even in countries with extensive social policies that aim to support people combining paid work and commitments outside work." They also point out Sue's focus on the need for both structural and cultural change in organisations. Kossek

\footnotetext{
${ }^{1}$ This is an Author's Original Manuscript of a paper that is now published in Community, Work and Family: Smithson, J., Chatrakul na Ayudhya, U., and Sullivan, C. (2016). From theory to impact: bringing work-life initiatives into the mainstream. Community, Work and Family. 19:2, 129-133. DOI 10.1080/13668803.2016.1134114.
} 
draws on Sue's efforts to bring work-life initiatives from the "margins" to the "mainstream." This highlights the contribution that Sue has made to the movement for research on work and families to have a strong emphasis on positive change, long before the current UK trend for evaluating research by examining its impact. Like many of her colleagues, Sue strove for this and encouraged others to do the same, because for her it makes research worthwhile.

\section{Critique of organisational discourses and the impact on employees' lives}

A second, related, important strand of Sue's work is her consistent critique of organisational discourses, and her demonstration of the impact of engaging in this critique. In particular she rejects the notion of "work-life balance", arguing instead, as Kagan and Lawthom state, that work and life should be conceptualized as integrated, rather than balanced. Rajan Rankin highlights Sue's influential critique of the neoliberal WLB discourse and the call for 'context' in work-life research. Brannen and Nilsen note Sue's increasing focus on the consequences of globalisation and new technology. A particular term of Sue's which several authors note is her attention to the importance of "layers of context" in understanding organisational and individual behaviour.

\section{Interdisciplinary approach: "Breaking down the disciplinary silos"}

Another key feature of Sue's work is her ability to work across disciplines, both in use of theory, and in an ability to connect with different ideas in other fields of expertise. Cooper and Gatrell describe this as "breaking down the disciplinary silos" between the fields of sociology, organizational psychology and management. They argue that this has brought a richness to the field which enables cross disciplinary understandings and facilitates critiques of both research and practice. Brannen and Nilsen's discussion of working with Sue on cross-national and interdisciplinary projects also highlights how skilled Sue is in working collaboratively with researchers from other disciplines in challenging contexts, and in responding to and encouraging the collaborative efforts of others. Community, Work and Family has always been an interdisciplinary journal and this reflects Sue's important role in the tradition of cross-disciplinary analyses of work, family and community.

\section{Feminist theory: focus on contextualised, gendered experience}

Most of the authors highlight the primacy of gender in Sue's work. Cooper and Gatrell refer to Sue's identification of gender as a "deeply ingrained, often troubling theme within worklife balance literatures." They suggest that "Her consistent call for work-life balance research to look beyond the narrow focus on heterosexual dual earner couples has enabled the articulation of gendered values and practices in organizations over a twenty year period".

Brannen and Nilsen note that Sue focused on "the ways in which organisations are gendered and act in gendered ways". Kagan and Lawthom argue that Sue has shown how flexible working arrangements in organizations are gendered policies. Several papers focus predominantly on Sue's processual and gendered approach to sense of entitlement. Both Chatrakul Na Ayudhya and Smithson, and Pitt-Catsouphes and McNamara discuss how Lewis's work on sense of entitlement to work-life balance particularly highlights this as situated in a specific time and place, and is shaped by gendered norms. As Rajan Rankin sees it, the central message of Suzan Lewis's contribution to work-life research is that: "context matters."

\section{Feminism in practice: Research leadership and collaboration}


In addition to her influence on theory and her challenging of organisational practice, those of us who know Sue also recognise her excellent collaborative management skills and her ability to bring diverse colleagues out of their different silos and into collaboration.. Brannen and Nilsen discuss the collaborative role that Sue played both through initiating projects across universities in the UK but also across Europe and more widely. They argue that "one of her hallmarks is her considerable skill as a mediator and collaborator. Sue leads in ways that always make working with or for her a positive experience. Furthermore, such is Sue's ability as a research leader that she rarely draws attention to her senior status and authority." Kagan and Lawthom note that Sue's work is "always in collaboration with others."

\section{Personal friendships, mentoring and support}

A final shared theme which comes out of the contributions to the special issue is Sue's support for colleagues, and her mentoring of early career researchers. Colleagues note Sue's "wonderful sense of humour and complete lack of self-importance, [which] has made working with Sue an experience of pure joy". They talk about her long-standing friendship and support, her "inspiration for my research in the work-life arena", how she is "exceptionally supportive, encouraging, and caring."

Collectively, the papers of this special issue highlight many aspects of the positive contribution that Sue Lewis and her work have made in the area of multiple roles research. We are all proud to have this opportunity to recognise Sue's tremendous capacity for encouraging effective collaboration and for to celebrate how she has supported and inspired colleagues across many years. In this collection of articles we see the lasting impact of the drive to examine this area in a way that is contextually sensitive, inter-disciplinary and action oriented and it becomes clear how much of a vital role Sue has played in this drive.

Cooper and Gattrell focus on Sue's observations about career advancement, gender, and a sense of entitlement (or otherwise) among employed mothers and fathers. They build on Lewis's (1997) notion of 'entitlement' among and between employed parents regarding access to family friendly and/or flexible working and personal career advancement. They extend Lewis's ideas through developing a framework which reflects the relative sense of entitlement (or lack thereof) among fathers and mothers in relation to work-life integration.

Pitt-Catsouphes and McNamara refer to Sue's life course approach to the study of worklife and entitlement, in their study of age-related expectations for work and family life. They examine whether the relationships between the respondents' personal biographies (such as perceived career stage and gender) and social history (such as country context) affect perceptions of age-related norms.

Brannen and Nilsen draw on the EU-funded research they conducted with Sue, with consideration of the development of work-family research in the UK and cross nationally, and the critical contribution of Suzan Lewis to this field. They focus on two studies which Sue led: Young people's views about their future work and family lives (Futures on hold); and Gender, Parenthood and the Changing European Workplace (Transitions). The paper points to some of the key prerequisites necessary for working in cross-national research teams and the conduct of high quality, qualitative cross-national research, especially studies that address different layers of social context.

Kagan and Lawthom build on the Sue's work on women's decision- making processes on work and care. They draw on data gathered from a forced labour project, and present some 
composite narratives from women as daughters, mothers and wives. These highlight the role of the core economy in decisions about migration for work, and present the complex decisions made by women around precarious work, present and distant 'families' and care. They suggest that future work-life research should heed Lewis' call for more nuanced understandings of the multi-layered context of people's experiences, workplace practices and relevant national policies, but also that it should go beyond this, and to pay attention to the globalised forces underpinning ever greater inequity in work, in families and in communities.

Den Dulk, Peper, Kanjuo Mrčela and Ignjatović also focus on Sue's attention to "layers of context." Their comparative study includes data from four organizational contexts in two countries, the Netherlands and Slovenia, to examine the role of different types of supervisory support (specific family support and general support) and the quality of the relationship between supervisor and subordinate (LMX) in work-to-family conflict, enrichment and worklife balance satisfaction. They conclude that in a context with a high level of national policy support, some dimensions of family support are seen as part of general supervisory support. Moreover, the role of supervisory support and the leader-member exchange relationship differs between organizational contexts and the outcomes considered.

Chatrakul Na Ayudhya and Smithson take Sue's work on sense of entitlement as a key theory to examine sense of entitlement to work-life support for a particular cohort - the "Millennial Generation". They draw on data from a study of young adults leaving university in the UK, which was inspired by Sue's work. Their analysis examines the ways in which these young adults discuss entitlement to employer support for work-life choices. They argue that this analysis challenges the notion of today's younger workers as more 'entitled' than previous generations, and relate this to contextual factors for this generation, in particular the changing nature of employment expectations in a globalised neo-liberal context.

Rajan-Rankin also draws on Sue's critical treatment of 'work-life balance' as a western, neoliberal discourse. She uses data from a study of call centre workers in India to highlight the problematic assumptions of gender and culture neutrality in the dominant discourses of worklife balance as these are translated and adopted within transnational organisations. She pays attention to how work-life balance terminology and discourses were used to describe a form of 'global modernity', an extension of professionalism and neoliberal working practices. This contrasted with shop floor experiences, however, where organizational cultures were heavily paternalistic and the workplace was viewed as an extended family whose role was to nurture, care for, and protect workers.

Kossek builds on Sue's argument that argument that work-life interventions can have broad societal impacts. Her paper explores the impact of work-life interventions on organizational change. She specifically examines the impact of a work- life assessment (flexstyles) which is designed to help individuals assess their boundary management styles, and a Family Supportive Supervisory Behavior (FSSB) training intervention for leaders. She concludes that interventions can (and should) be evaluated for impacts on a triple bottom line (outcomes for employees, employers and society).

\section{Notes on Contributors}

Janet Smithson is senior lecturer at the University of Exeter, and a social psychology researcher. Her main research interests include gender and discourse, work-life practices and policies, life course transitions, qualitative methodologies, internet-mediated discourse and 
communication, organisational change, cohabitation, prenuptial agreements and alternative dispute resolution after separation or divorce.

Uracha Chatrakul $\mathrm{Na}$ Ayudhya is senior lecturer in Organizational Behaviour at MiddlesexUniversity Business School. Her broad research interests include life course transitions and qualitative methodologies. She has conducted studies exploring work-life balance experiences among new labour market entrants and older workers' experiences of extended working lives. As a former international student and then a migrant worker, she is also interested in exploring international students' experiences as temporary migrants in the UK. She is an associate editor of the journal Community, Work and Family.

Cath Sullivan is Senior Lecturer in Psychology in the University of Central Lancashire's School of Psychology and her research interests mainly relate to the social psychology of gender and social roles. Cath has been researching issues relating to "work-life balance" for many years, has served on the organising committee of the International Community, Work and Family conference, has acted as a member of the selection panel for the Kanter Award for Excellence in Research on Work and Family several times and her publications include various articles and book chapters in this area.

\section{References}

Kagan, C. and Lewis S. (2015). Community, Work and Family and the metamorphosis of social change. Paper presented to Community Work and Family Conference, Malmo, May 2015 . 